\title{
Crisis Management Actions in the Egyptian Travel Agencies: A Managerial Perspective
}

\author{
Yasser Moustafa Shehawy ${ }^{*} \quad$ Ahmad Muhammad Ragab ${ }^{* *}$
}

(*) Lecturer, Tourism Studies Department, Faculty of Tourism and Hotels, University of Sadat City, Egypt, and Faculty of Arts and Humanities, Jazan University, K.S.A,

(**) Lecturer, Tourism Studies Department, Faculty of Tourism and Hotels, Minia University, Egypt.

\begin{abstract}
The Egyptian tourism destination is suffering severe losses since 2011. Travel agencies business, among others, is one of the most affected sectors during the current crisis. Given that, this study aims to empirically investigate high-level management actions during crises with emphasize on the travel agencies business in Egypt. A quantitative questionnaire is designed and data is collected from 211 managers in different types of travel agencies in Egypt. The findings reveal that marketing actions should be adopted as the top crisis management focusing on co-marketing with other tourism suppliers (e.g. airlines and hotels), provide special offers with discounted rates, targeting new market segments, and marketing and promotion of new products (e.g. special events). Also, the actions associated with government support are among the most important crisis management actions to be adopted, such as request longterm government assistances, and request an installment payments agreement (e.g. taxes, loans). Moreover, the results indicate that travel agencies type (A, $\mathrm{B}$, or C) and ownership structure (national, foreign, or partnership) are the main characteristics influencing travel agencies actions during crises. This study presents a list of actions that can help travel agencies managers in Egypt on relieving the negative effects of a crisis and supporting the development of an efficient crisis management action plan.
\end{abstract}

Keywords: Tourism crisis, crisis management, travel agency, tourism in Egypt.

\section{Introduction}

Globally, tourism industry can be defined as a human service industry that is sensitively affected by numerous events or crisis rather than other economic industries. It includes, in most cases, travelling internationally outside the political and geographical boundaries, so that it is disposed to crises as it is highly fragmented and complex with many interdependencies among its sectors (Paraskevas and Altinay, 2013). Wang (2009) and Akova, et al. (2011) concluded that tourism industry is universally affected by external factors easily and quickly such as politics, wars, diseases, global economic crises and other factors. Therefore, the tourism planners and business suppliers in destinations have to understand the sensitive characteristics of tourism with respect to these external factors. Also, they should develop organized action plans and flexible strategies to provide best tourism services for tourists during crisis periods and searching for different alternative tourism markets. 
Henderson (2007) and Lovelock, (2004) stated that tourism crises negatively influence flows of tourists as well as destination choices with serious impacts on hotels, attraction and air transport providers in addition to other tourism stakeholders such as tour operators, travel agents and the destination's tourism authorities. Monica and Raluca (2008), and Yaron and Aviad (2011) illustrated that direct or indirect events and those that are generally or in the geographic context connected to tourism may have a huge impact on tourism activities. For example; the Asian financial crisis witnessed in 1997, the 11 September 2001 World Trade Centre terrorist attacks, the global financial crisis of August 2008, the SARS epidemic outbreak, the Indian Ocean Tsunami, and other terror attacks around the world caused a sharp decline in the global tourism flows resulting in drawbacks in tourism businesses yields. (Ito and Lee, 2005; Rittichainuwat, 2006; Sausmarez, 2004; Pine and McKercher, 2004). This is confirmed by Akova, et al., (2011) who mentioned that political instability, economic recession, disasters, terrorist attacks or the outbreak of a war in one part of the world can dramatically reduce tourist travel patterns to other parts of the world. Likewise, Wang (2009) found that instabilities on safety and whether status, domestically or internationally, would negatively affect tourism demand, but the impact of financial crises on this demand is less significant. From this sprang, many scholars (Lovelock, 2003; Ito and Lee, 2005; Akova, Sarışık, and Dönmez, 2011; Kukanjaand and Planinc, 2013; Avraham, 2015) have studied the impacts of crises on tourism industry as well as proposed many models and strategies for crisis management in the destination level as well as the tourism business level.

Since 2011, Egypt is facing a sharp decline in number of inbound tourists causing a real tourism crisis for travel agencies business, among others, in the Egyptian tourism destination. This paper aims to empirically investigate the actions that should be adopted by travel agencies in Egypt during a crisis to face the challenge of decreased demand levels. Through surveying the opinions of managers at different categories of travel agencies, a list of the most important actions is to be recommended.

\section{Literature Review}

\subsection{The crisis management in tourism}

The most comprehensive and cited definition of the tourism crisis is presented by Sonmez, Backman, and Allen (1994: 22) who defined a tourism crisis as "any occurrence which can threaten the normal operation and conduct of tourism related businesses, damage a tourist destination's overall reputation for safety, attractiveness and comfort by negatively affecting visitors' perceptions of that destination; and, in turn, cause a downturn in the local travel and tourism economy and interrupt the continuity of business by the reduction in tourist arrivals and expenditures". Akova, et al. (2011) introduced that if any crisis aroused, the repercussions extend directly to the activities that are associated with tourism, namely, travel agents, airlines, hotels, and catering. Also, these repercussions reach to both destination supplying intermediates and employees in the tourism industry. Consequently, all tourism activities and 
related activities are affected to a greater or lesser extent. To manage crises effectively, Mitroff (1988) proposed a five phases or mechanisms of crisis management model which are: signal detection, preparation/ prevention, containment (damage limitation), recovery, and learning. Akova, et al., (2011) and Ritchie (2004) reviewed that the policies for the crisis should be prepared by all destination and business managers, sectors and organizations. It is also important to ensure that in the rush to return to the status quo, valuable lessons are not forgotten which would help guide responses to the next crisis which will inevitably occur.

Generally, Avraham (2015), Paraskevas and Altinay (2013), Pforr and Hosie (2007), and Ritchie (2004) summarized four clearly defined streams of research in the area of crisis management in tourism. Firstly, the focus was on crises impacts on tourism to reduce or mitigate these impacts by improving the response management. Secondly, research empathized on the recovery reactive approach of crisis communication techniques determining the damage and rebuilding destination image through communications and marketing initiatives. This includes three media strategies namely source, message and audience used by marketers to restore a positive destination image. Thirdly, research scopes extended to investigate the importance of pre-crisis stage. Hence, travel and tourism organizations and tourist destinations plan and prepare for crisis events which may occur in the future. Fourthly, the studies on crisis management in tourism highlighted integrating the extant knowledge of generic crisis and disaster management, and proposing succinct strategies, models and frameworks for a 'holistic' crisis/disaster management in tourism. Ritchie (2004) designed three main stages model in outlining approach to crisis planning and management which are: prevention and planning, implementation, and evaluation and feedback. Similarly, Wang (2009) explained that the strategies for managing crisis that can affect tourism should be handled by both governments and tourism firms.

\subsection{The crisis management in travel agencies}

It is suggested that crisis management actions and strategies have to be positioned in the context of the particular socio-cultural, economic, political, historic and physical environment characteristics (Pforr and Hosie, 2007). The literature on crisis management practices in travel agencies is sparse (Yaron and Aviad, 2011). Sonmez et al (1999) and Santana (2004) examined that the tourism destination under crisis should integrate crisis management action plan into their inclusive tourism sustainable development, marketing, and management strategies to maintain and rebuild their image of safety and attractiveness, to reestablish the area's functionalities, and to aid local travel and tourism industry members in their economic recovery. For travel agencies, crisis situations are intensifying for two additional reasons. The first includes the growing tendencies of airlines to reduce and sometimes eliminate the commissions paid to agents. The second includes the growing popularity of internet-based reservation systems, which are a more accessible and sometimes less expensive compared to the traditional travel agent (Yaron and Aviad, 
2011). Thus, crises in the field of tourism are not only causing yield reductions in tourism business and travel agencies, but also threatening the existence of these travel agents as economic service entities operates employment and provide travel programs planning services. Thus, the crucial crisis management can effectively be triggered through coordination and collaboration between travel agencies and other key tourism stakeholders in a destination (McKercher and Chon, 2004). Generally, Pforr and Hosie (2007) identified the following outlines for crisis management action plan strategies in the business environment of travel agencies:

1) Putting a detailed and realistic emergency plan to deal with crises;

2) Identifying the complexity of the crisis and effects limitations;

3) Describing the responsibilities;

4) Integrating businesses with the strategic planning processes;

5) Planning and training;

6) Effectively understand the crisis comprehensively; and

7) Ensuring the compatibility between operational and strategic levels to react crisis swiftly and decisively.

Through reviewing the relevant literature (Beirman, 2003; Sausmarez, 2003; Pforr and Hosie, 2007; Monica and Raluca, 2008; Wang, 2009; Akova, et al., 2011; Yaron and Aviad, 2011; Lahav, et al., 2013) it is clear that the most adopted practices by travel agencies cover four main categories which are: 1) human resources, 2) marketing, 3) infrastructure maintenance, and 4) governmental or external assistance. The following showed a detailed description of each practice.

\subsubsection{Human Resources in crisis management of travel agencies:}

Monica and Raluca (2008), and Pforr and Hosie (2007) abstracted that human resource development (HRD) is promoted as a key effective component to respond and meet successively controlling of crises. More, the tourism and hospitality industry is labor intensive; therefore, practices in the human resources aspects are central to crisis management mitigation issues. The human resources development needs to be different conceived and operated as a particular preparation to deal with crises at the individual levels of the organization through integrated use of training and development, organizational development, and career development to improve individual, group, and organizational effectiveness in the face of crisis (Monica and Raluca, 2008; Pforr and Hosie, 2007). The most common practices with respect to human resources during crisis are illustrated in figure 1.

\subsubsection{Tourism Marketing in crisis management of travel agencies}

Marketing is a central element in combating crisis and building flexible and alternative marketing strategies in travel agents to deal with the effects of certain crisis is deemed to be one of the most powerful crisis management action plans. According to Sausmarez (2003) tourism marketing strategies supported by the Malaysian government helped to increase domestic and inbound tourism in the aftermath of the Asian financial turmoil. In the same 
way, Wang (2009) stated that governments can also be one of the big sponsors for marketing strategies that can help the country overcome the negative impacts of the crises. Most common marketing practices in crisis management studies were as follows (Lovelock, 2003; Pforr and Hosie, 2007, Yaron and Aviad, 2011; Lahav, et al., 2013):

a) Integrating crisis marketing and communication strategy

b) Fostering effective coordination and partnership between appropriate stakeholders

c) Diversified tourism advertising on different media channels

d) Maintaining positive relationships with the mass media throughout crisis recovery

e) Reducing prices on special package-tours offers

f) Reducing list price of office services or commissions for groups

g) Re-branding destination image by creating and promoting tourism, patterns, events and exhibitions

h) Rebuilding market environment by reevaluation of target markets

i) Marketing to new segments with accurate incentive criteria

j) Charging for services that were previously offered at no charge

k) Charging (or increasing the charge) for opening a customer file or order

l) Passing charges to customers (such as credit card transaction fees)

\begin{tabular}{|c|c|}
\hline \multicolumn{2}{|l|}{ Quality of HRD to maximize the power of agent's human capital } \\
\hline Employee training and development to improve HR effectiveness & \\
\hline Developing the crisis leadership principals and competencies & \\
\hline Downsize employees to reduce labor force & \\
\hline Using unpaid vacation to reduce labor force & \\
\hline Reducing number of office hours in travel agencies & \\
\hline Management voluntary salary reduction & \\
\hline Cost effective or reducing pay rate & \\
\hline Replacing long-standing employees with new employees & \\
\hline Increased reliance on outsourcing & \\
\hline
\end{tabular}

Figure 1. Most common to human resources' practices during crisis

Sources: Pforr, C. and Hosie, P. (2007); Monica, C. and Raluca, D. (2008); Yaron, P. and Aviad A. (2011).

In this context, Beirman (2003) suggested the following steps to be adopted by tourism businesses for developing their marketing and management plans under the threating of a certain crisis:

Step 1: Identify the problem nature as a crisis where the official tourism destination authority needs to manage the answer of the following questions:

a. Will this problem widely negatively publicize in key tourism markets? 
b. Does it have the prospective to threaten the safety or well-being of tourists?

c. Were the traffics of tourists directly affected?

d. Have foreign governments altered travel advisories to avoid or inhibit travelling to the destination because of this problem?

e. Have insurance companies deleted or limited coverage to the destination?

f. Are airlines and tour operators considering withdrawing or limiting services and products to the destination because of this event or problem?

g. Are tour operators changing bookings rates to the destination?

h. Are the destination representatives overseas or interstate reporting a substantial growth of negative inquiries from the public and the travel industry?

i. Is there large growth in cancellations or decrease in advancing bookings?

j. Are tourism destination marketing media groups obviously delaying publications about the destination with or without clarification?

$\mathrm{k}$. Is there a statistically significant (seasonally adjusted) severe downturn in arrivals and hotel occupancy rates?

1. Is there pressure inside the tourism entities to reduce employment levels?

$\mathrm{m}$. Is there a domestic sense of political urgency regarding the prospects of the tourism industry?

n. Are national tourism receipts significantly (seasonally adjusted) reduced?

Step 2: Establish a tourism crisis management team where there are a number of elements involved in managing a destination crisis. At the management level, there may be a requirement for several teams to manage the crisis. The overall responsibility for crisis management in any destination authority rests with the crisis chief executive officer (CEO) or an appointed crisis manger, who will normally establish global guidelines. In the destination management organization, there may be regional or national factors which require variations from the head office approach. The major elements, especially from a marketing perspective, include media and public relations action plan, relations with the travel industry in source markets, operations and situation assessment and dissemination focusing on internal national/ international staff and the industry within the destination, destination response coordination with the local tourism and hospitality industry, contact relation with local/ regional and national government authorities, government advisories and travel insurance, and implementation of alliances with tour operators, airlines, shipping lines and/ or land transport providers which serve the destination.

Step 3: Promoting the destination during and after a crisis by several marketing approaches. Activities should include isolation marketing segmentations, incentives to restore the tourism market; maintaining an effective website; and ensuring that opinion leaders in source markets see for themselves.

Step 4: Monitoring recovery and analyzing the crisis experience. So that, to cope with crisis tourism entities it is essential to apply varied strategies; for example luxury hotels can rely on marketing strategies to attract new customers, while budget can offer discounts. The tourism service provider can adjust work-time, functional and numerical flexibility. 
Tourism firms can also promote themselves to new markets and can change their marketing strategies according to domestic and global market. In the USA to restore the US travel and tourism industry economic health levels to preSeptember 11 they formed The Travel Industry Recovery Coalition (TIRC) (TIA 2002) which made six main procedure including: the federal government provide a $\$ 500$ tax credit for travel originating and occurring within North America on air, cruise, train, bus, rental car, and hotel/ motel expenditures, expand loan programs to small businesses, offer a workforce tax credit for employment in the industry, supply substantial federal funding for marketing campaigns, increase tax allowances to enable businesses to offset losses sustained because of this crisis against future earnings, and restore full tax deductibility for business entertainment expenses that are currently only 50\% deductible (Blake and Sinclair, 2003). Likewise, in Turkey, the Turkish government invested on new tourism products where price-and quality of tourism services has balanced, choose tourism market segment as European tourists who want to stay long and pay less, and compensated employees and the tourism firms by late payment of excise taxes and labor tax compensation to the tourist firms that have been effected by the economic crisis during 2008 (Akova, et al., 2011).

\subsubsection{Infrastructure maintenance in crisis management of travel agencies}

It can be highlighted that crisis long term recovery can be enhanced by strong and good infrastructure (Pforr and Hosie, 2007; Ritchie, 2004). The maintenance category is aimed at reducing costs of operations. As stated in literature, this category includes four practices of cutting maintenance costs as shown in figure 2 .

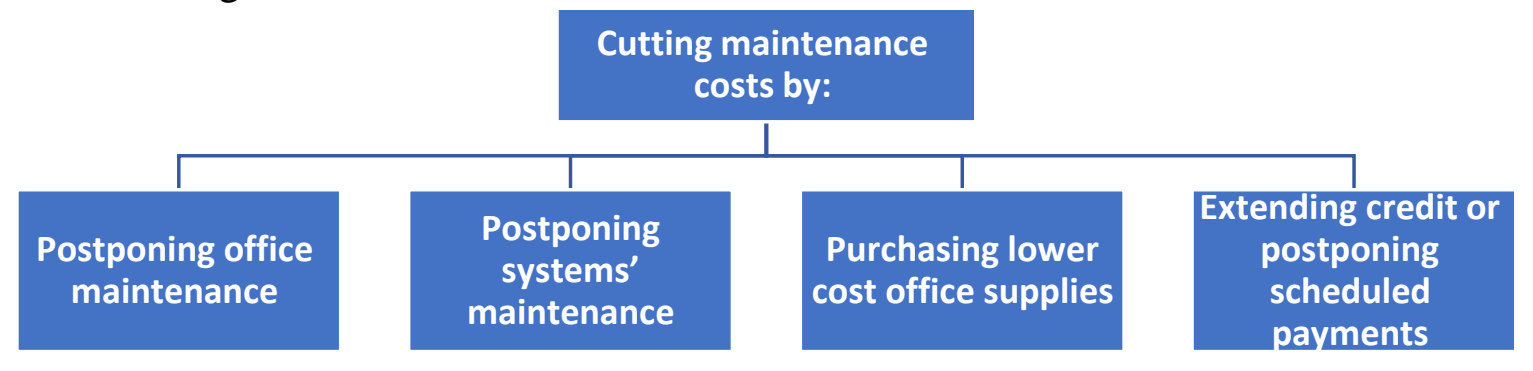

Figure 2. Practices of cutting maintenance costs during crisis

Source: Yaron, P. and Aviad A. (2011).

\subsubsection{Governmental or external assistance in crisis management of travel agencies}

Akova, et al., (2011) mentioned that to cope with a crisis, governments need to implement a range of policies to offset the crisis. Also, governments are faced with the difficult decision of what measures to take, particularly since the implementation of many measures is costly and their relative effectiveness varies. The government and external support category included different 
practices that focus primarily on requesting support from governments and other related bodies. Pforr and Hosie (2007) recognized that the government aid packages in oversensitive tourism crisis management presented for accommodation and transport sectors, promotion of domestic tourism, marketing of new specific tourism niche, and creating new tourism norms. Also, a practice of protesting against lack of support is among the government support practices during crisis. Examples of these practices are as follows: (Yaron and Aviad, 2011):

a. Organized protest against the lack of government support;

b. Industry-wide demand for governmental assistance with current expenses;

c. Industry-wide demand for a grace period on tax payments or eliminations;

d. Industry-wide demand for a grace period on local tax (municipality) payments;

e. Communicating 'business as usual' was added when they do not receive or expect any government intervention; and

f. Joining a travel agency chain was included to improve efficiency and to improve the ability to negotiate with suppliers.

Akova, et al., (2011) reviewed that after September 11, the US government passed a $\$ 15$ billion relief package that helped its faltering tourism industry recover, and this saved many businesses from bankruptcy. Blake and Sinclair (2003) examine the low season of the US tourism industry after the September 11 attacks and found that tax reductions were the most efficient way to handle the crisis. In this sense, Sonmez et al., (1999) illustrated that for governments to cope with a tourism crisis, it is necessary to create a crisis roadmap or action plans in respond to shocks, launching a tourism crisis management task force, developing a crisis management guidebook, and partnering with law enforcement officials. The strategies that government can apply for the tourism firms and related sectors are; tax reductions, compensation to tourism firms and related sectors, increased insurance premiums; limitation of the extent of liability by tourism firms and related industries for the results of global economic crisis; allowances to make late payment of excise taxes and compensation to employees. Governments can pass relief package that can help faltering tourism industry recover, and so can save many businesses from bankruptcy (Wang, 2009; Wang, 2010; Akova et al., 2011).

\subsection{Recent Tourism Crisis in Egypt}

Since 2011, tourists as well as tour operators' confidence in Egyptian tourism destinations have been hit. The political turbulence led tourists to change their travel to other destinations with more stability. Egypt received about 9.8 million tourists in 2011 with a decline rate of 33\% than the year of 2010 (the peak year for Egyptian tourism) and nights reached almost 114 million, with a decrease of $29 \%$ compared to 2010. Since then the figures continued to decline, reaching to the lowest rates in 2014 and 2015 over the course of the last nine years in Egypt. The compound annual growth rate between 2010 and 2015 recorded a negative annual rate of $9 \%$ for tourist and $11 \%$ for nights (Figure 3 
and 4). Indeed, the leading tourism business, hotels, travel agencies, and airlines were the most suffering sectors in economic terms.

\section{No of Inbound Tourists (million)}

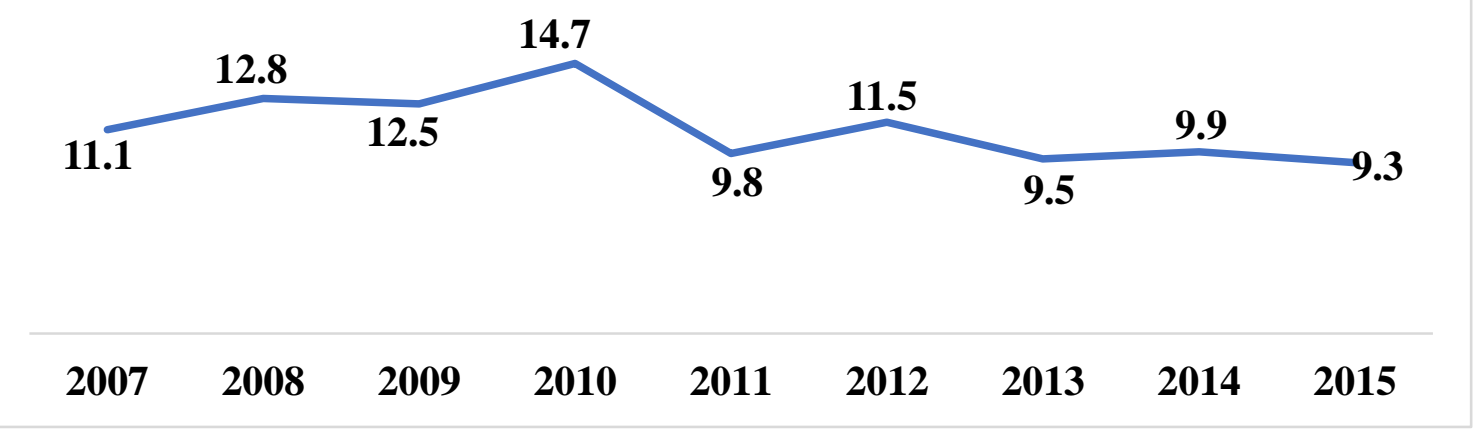

Figure 3. Inbound Tourism in Egypt, 2007-2015

Source: Prepared by the Authors based on: CAPMAS (2016)

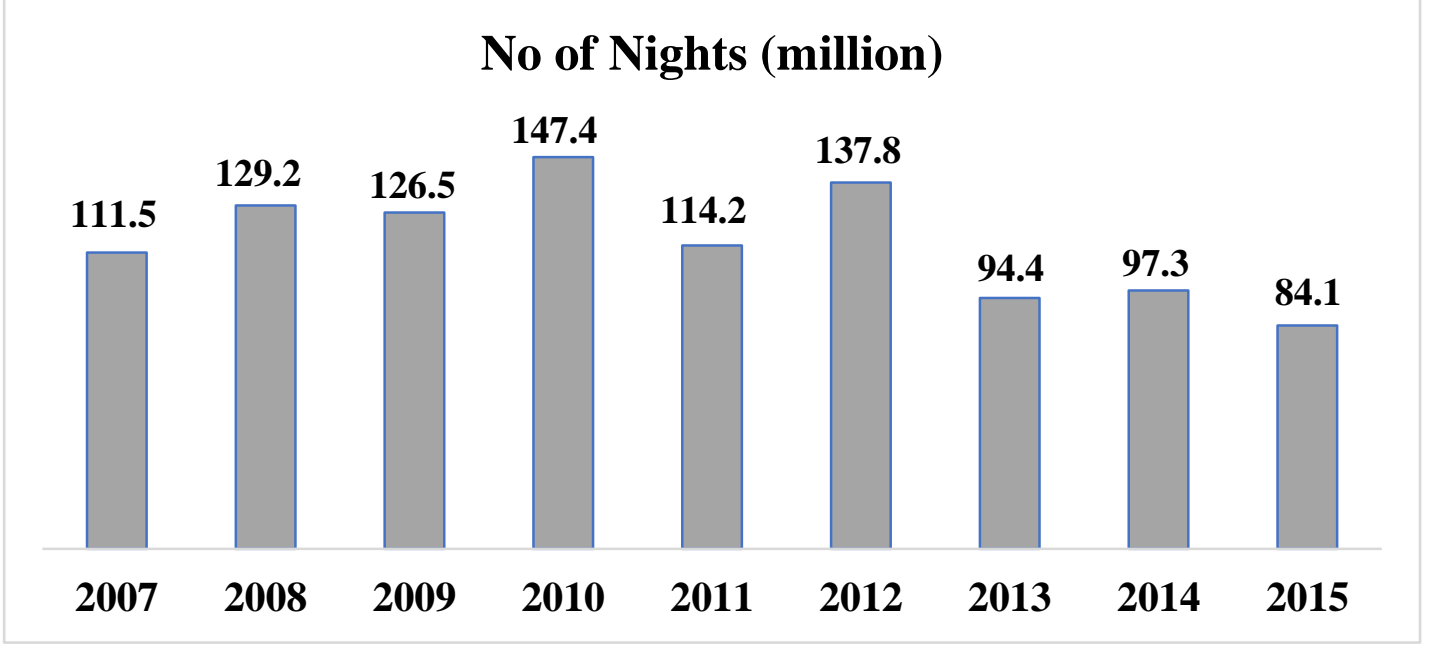

Figure 4. Number of Inbound Tourist Nights in Egypt, 2007-2015

Source: Prepared by the Authors based on: CAPMAS (2016)

From a legislative point of view, travel agencies in Egypt are classified into three categories: A, B and C. The category A of travel agencies carries out all kinds of activities that are related to travel and tourism. The category B is allowed to work only on ticketing while $\mathrm{C}$ category is responsible for operating means of transportation (GAFI, 2015). Travel agencies in Egypt witnessed a remarkable increase from 1982 with only 331 companies to 2241 companies in 2013. However, in 2014 and 2015 this number declined sharply to register 1302 companies (Figure 5), seemingly this decline that happened in these last two years explained by the current crisis.

\section{The study questions}

The present study aims to investigate managers' opinions on their high-level management actions during crises with emphasize on the travel agencies sector in Egypt. More specifically, two research questions were formulated to be answered thorough this study: 
Q1) what are the most important actions should be adopted by travel agencies in Egypt during crises?

Q2) what are the travel agencies' characteristics that influence their actions during crises?

\section{Methodology}

\subsection{Participants}

The target population for this study was mangers in the different management levels at the three categories of travel agencies in Egypt. Due to the difficulty to reach to details on number of employees in each category of travel agencies in Egypt in general and the number of managers in particular, simple random sampling method had been used. "Simple random sampling is a sampling design in which $k$ distinct items are selected from the $n$ items in the population in such a way that every possible combination of $k$ items is equally likely to be the sample selected" (Meng, 2013:1).

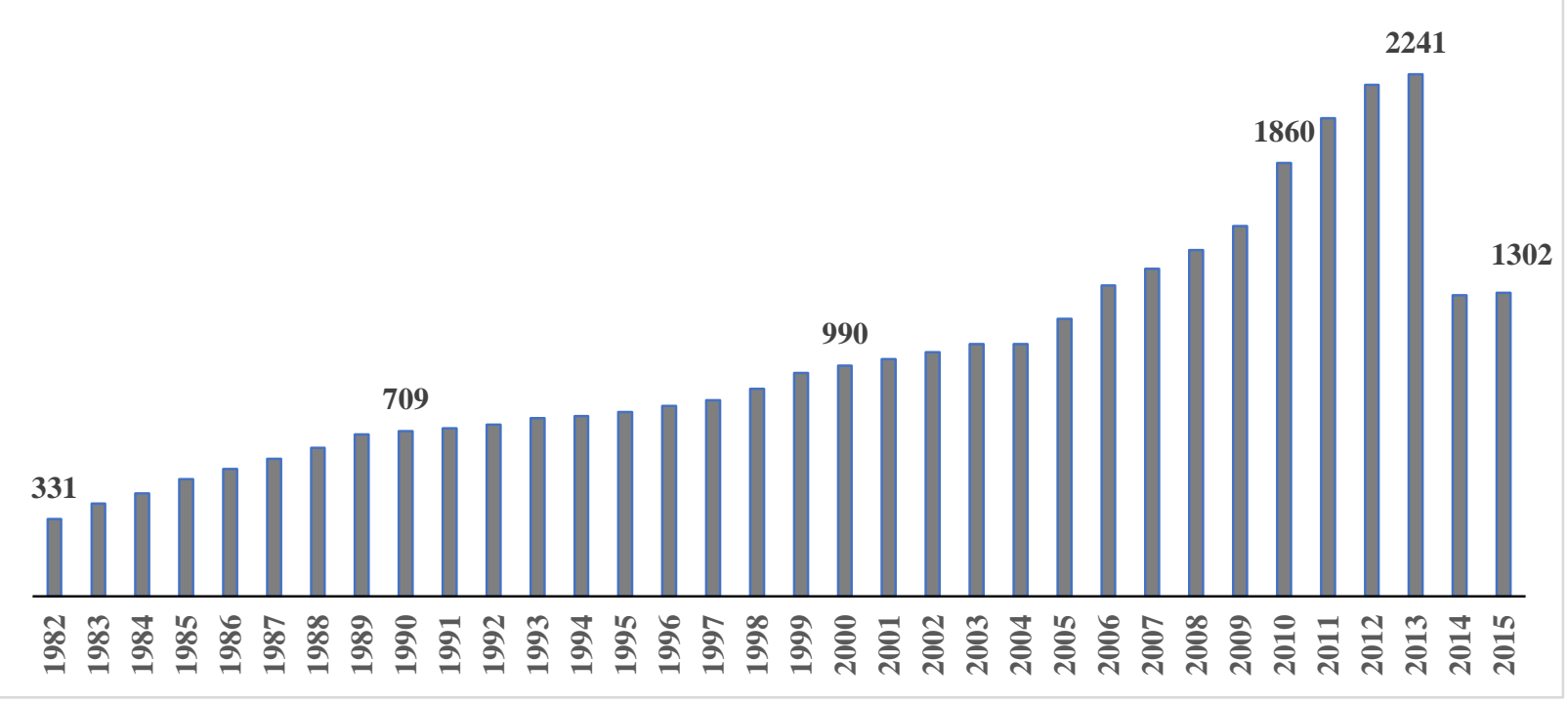

Figure 5. The growth of travel agencies in Egypt (1982-2015)

Source: IDSC (2016). Statistical Indicators: Number of travel agencies. Cairo.

\subsection{Study instrument}

The survey instrument involved four dimensions (human resources, marketing, cost reduction, and government support) as suggested by Yaron and Aviad $(2003,2011)$ who developed a model to assess crisis-management practices in the hospitality industry. The researchers of this study at hand adopted 21 statements in the Arabic language to examine the diverse actions that could be followed by travel agencies in Egypt during crises. Also, few modifications were made to the dimensions of Yaron and Aviad's model to adjust them to the tourism business environment in Egypt. The questionnaire was pre-tested by 30 respondents to ensure that targeted participants understand the questions clearly and to assess the reliability of the scale used in this current study. Ageron and Courvoisier (2014) suggested that 30 participants is a reasonable sample size for pre-tests of questionnaires. Then, the questionnaire uploaded at an online 
survey management tool (esurv.org) and participants were invited to take that survey. This online survey was open from August 2015 to May 2016 and the targeted participants were reminded of contribution many times during that period. Consequently, 211 complete responses were collected and all of them were valid for this study analysis. Participants were asked to report their opinion on a five-point Likert scale $(1=$ strongly disagree, $5=$ strongly agree $)$ for each of the 21 questionnaire statements. "Cronbach's Alpha reliability test is used by averaging the coefficient that results from all possible combinations of split halves" (Malhotra, 2004: 51). The Alpha coefficient varies from 0 to 1 and a value less than 0.6 indicates unsatisfactory internal consistency, values from 0.6 to 0.8 are moderate strong and values from 0.8 to 1.0 are very strong in reliability (Malhotra, 2004). The results revealed that the internal consistency, Cronbach's coefficients, for the 4 dimensions of this study were of moderate strong levels, which were ranged from 0.64 to 0.85 . (Table 1)

Table 1: The internal reliability coefficients of the study dimensions

\begin{tabular}{|l|c|c|}
\hline Dimension & Reliability level & Number of items \\
\hline Human resources & 0.79 & 7 \\
\hline Marketing and Pricing & 0.64 & 8 \\
\hline Cost reduction & 0.74 & 3 \\
\hline Government support & 0.85 & 3 \\
\hline
\end{tabular}

\subsection{Data analysis}

Descriptive statistics analysis, including frequencies and distributions, was used to report on the demographic profile of the participants. KolmogorovSmirnov test is used to investigate the normality of the data sample distribution. Then, The Kruskal-Wallis $\chi^{2}$ test was used to identify the differences in the responses of surveyed managers on the basis of the of travel agency category (A, B. C), company's operating years ( $<5$ years, 5-9, 10-15, > 15 years), and company ownership structure (national, foreign, partnership). The Mann-Whitney U-test was used to identify differences in the opinions of managers on the basis of the company size (SMEs vs. large enterprises).

\section{Results and discussions}

\subsection{The profile of respondents}

The respondents' profile showed that the majority of participated managers were from the travel agency category (A) (69\%). Also, most of them work in travel agencies with more than 10 years' presence in the Egyptian tourism destination. Nearly $76 \%$ of respondents are affiliated to small and medium enterprises. Lastly, approximately a two-third of the respondents (66\%) works in national companies (Table 2).

\subsection{Impact of the current tourism crisis on travel agncies business}

Respondents were asked to report on their opinions about the extent that their travel agnceies have been affacted by the current tourism crisis in Egypt. As expected, the majority (45\%) believed that travel agncies business are facing very bad situation during this current crisis (Figure 6). 
Table 2. Profile of the respondents

\begin{tabular}{|c|c|}
\hline Characteristics $(\mathbf{n = 2 1 1})$ & Relative Frequency (\%) \\
\hline Travel agency category & 69 \\
A & 17 \\
B & 14 \\
C & 3 \\
\hline Company's operating years & 14 \\
< 5 years & 41 \\
5-9 & 41 \\
10-15 & \\
$>$ 15 years & 76 \\
Company size & 24 \\
SMEs & \\
Large enterprise & 66 \\
Company ownership & 7 \\
National & 28 \\
Foreign & \\
Partnership & \\
\hline
\end{tabular}

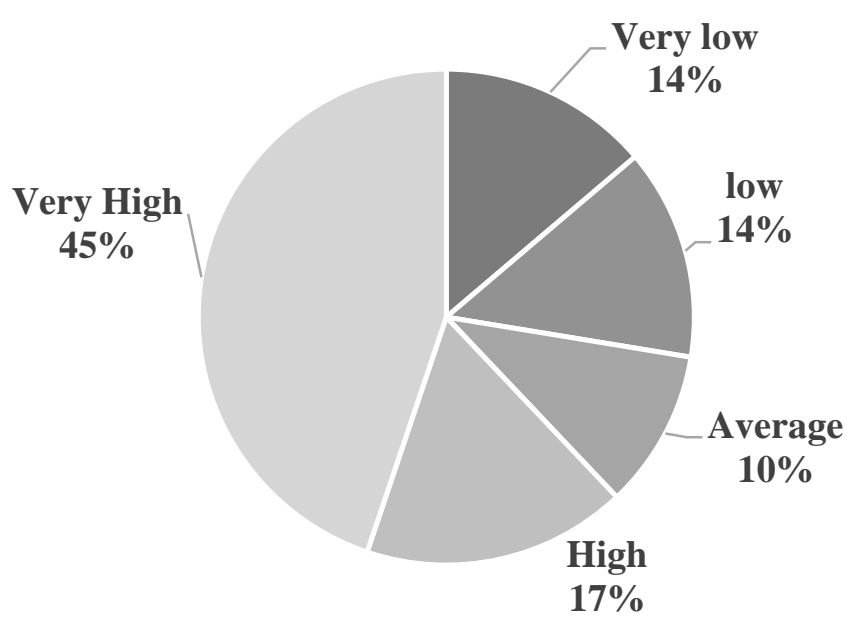

Figure 6. Respondents' opinion on the current crisis effects travel agencies

In the same sense, respondents were asked to illustrate their views on their companies' plans for future investments. More than the half said that no investments plans and $28 \%$ mentioned that their companies will definitely not invest anymore in the future, as presented in (Figure 7). These results reflect the uncertainty status that is surrounding the Egyptian tourism destination during this current crisis and may refer to the lack of clear crisis management strategies. 


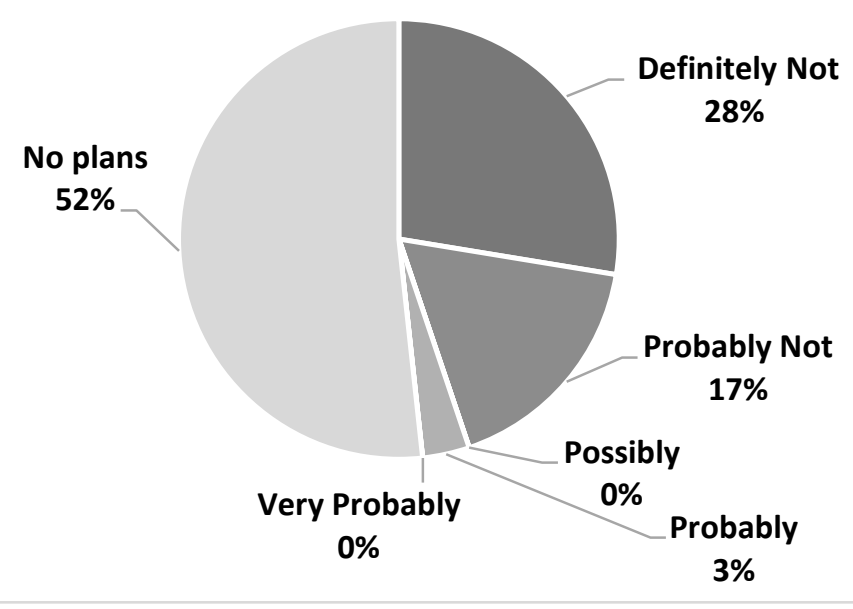

Figure 7. Respondents' opinion on their companies' planned future investments

\subsection{Assessment of the importance of crisis management actions}

Table 3 illustrated the total score for each item through calculating the mean of each respondent's answers across all statements/items in the study's scale. It showed that the highest mean $(\mathrm{M}=4.40, \mathrm{SD}=0.764)$ was associated with the "marketing" dimension; "co-marketing with other tourism suppliers (airlines, hotels)", "provide special offers with discounted rates" $(\mathrm{M}=3.93, \mathrm{SD}=$ 0.997), "targeting new market segments" $(\mathrm{M}=3.89, \mathrm{SD}=1.188)$, and "marketing and promotion of new products/ services (special events)" ( $\mathrm{M}=$ $3.46, \mathrm{SD}=1.272$ ). Also, the actions associated with "government support" dimension scored high mean; "request long-term government supports" and "request an installment payments agreement (taxes, loans)" $(\mathrm{M}=4.04, \mathrm{SD}=$ 1.113). While the lowest scores were associated with the actions that target "human resources"; "reducing senior management salaries" $(\mathrm{M}=2.62, \mathrm{SD}=$ $1.472)$, reduction of working hours/ days $(\mathrm{M}=2.33, \mathrm{SD}=1.468)$, "reducing all employees' salaries" $(\mathrm{M}=2.23, \mathrm{SD}=1.243)$, "terminating some employees" $(\mathrm{M}=2.04, \mathrm{SD}=1.160)$, "giving employees unpaid leaves" $(\mathrm{M} 2.04, \mathrm{SD}=$ $1.285)$, "replacing high-wages staff with low-wages new ones" $(2.00, \mathrm{SD}=$ 1.177), and "reliance on outsourcing" $(\mathrm{M}=2.00, \mathrm{SD}=1.177)$.

These results answered the first questions of this study at hand determining the marketing and government support as the most adequate actions to be adopted by travel agencies during crises in Egypt. These results were consistent with the findings of Aviad, Mohsin, and Kumar (2011) who found that government support and marketing efforts can assist in increasing the volume of potential business transactions during crisis with reference to the Indian luxury hotels. On contrary, these present study's results were not in line with Yaron, and Aviad (2011) who concluded that cost reduction is the most important action to be practiced travel agencies during crisis 
Table 3. Respondent's opinions on the importance of crisis management actions

\begin{tabular}{|c|c|c|c|}
\hline \multicolumn{2}{|r|}{ Item } & M* & SD \\
\hline \multicolumn{4}{|c|}{ A. Human Resources } \\
\hline A.1 & Lay off some employees & 2.04 & 1.160 \\
\hline A.2 & Give employees unpaid leave & 2.04 & 1.285 \\
\hline A.3 & Reduction of working hours/ days & 2.33 & 1.468 \\
\hline A.4 & Reducing senior management salaries & 2.62 & 1.472 \\
\hline A.5 & Reducing all employees' salaries & 2.23 & 1.243 \\
\hline A.6 & Replacing high wages staff with low salaries new ones & 2.00 & 1.177 \\
\hline A.7 & Increased reliance on outsourcing & 2.00 & 1.177 \\
\hline \multicolumn{4}{|c|}{ B. Marketing } \\
\hline B.1 & Intensify marketing efforts on domestic tourism market & 2.91 & 1.505 \\
\hline B.2 & Advertising campaigns in the internet and social media & 2.92 & 1.623 \\
\hline B.3 & with other tourism su & 4.40 & 0.764 \\
\hline B.4 & Provide special offers with discounted rates & 3.93 & .997 \\
\hline B.5 & $\begin{array}{l}\text { Reduce prices for all services/products provided by the } \\
\text { company }\end{array}$ & 3.19 & 1.443 \\
\hline B.6 & $\begin{array}{l}\text { Marketing and promotion of new products/ services (special } \\
\text { events) }\end{array}$ & 3.46 & 1.272 \\
\hline B.7 & Targeting new market segments & 3.89 & 1.188 \\
\hline B.8 & Participation at international tourism trade/customer fairs & 3.08 & 1.230 \\
\hline \multicolumn{4}{|c|}{ C. Cost reduction } \\
\hline C.1 & $\begin{array}{l}\text { Cut-off costs by deferring maintenance on company } \\
\text { equipment (e.g. buses, software) }\end{array}$ & 2.69 & 1.314 \\
\hline C. 2 & Cut-off costs by purchasing cheap office supplies & 2.73 & 1.308 \\
\hline C. 3 & Defer owed operating payment (electricity, other expenses) & 2.81 & 1.524 \\
\hline \multicolumn{4}{|c|}{ D. Government support } \\
\hline D. 1 & $\begin{array}{l}\text { Organize official protests against inadequate government } \\
\text { assistance }\end{array}$ & 2.77 & 1.451 \\
\hline D.2 & Request long-term government supports & 4.04 & 1.113 \\
\hline D.3 & Request an installment payments agreement (taxes, loans) & 4.04 & 1.113 \\
\hline
\end{tabular}

*Note: $(\mathrm{n}=211)$, Scales values range from 1 (Strongly agree) to 7 (Strongly disagree. $\mathrm{M}=$ mean, $\mathrm{SD}=$ standard deviation

\subsection{Effects of travel agencies' characteristics on their actions during crisis}

At first, to numerically examine the normality of respondent's answers, Kolmogorov-Smirnov test (significance level of 0.05) was used. This test is suggested to be used when the sample size is less than 2000 and its results indicate the proper tests to further be used for comparing groups; whether parametric or non-parametric tests (Thode, 2002). As the results of table 4 showed that the test statistics for all study's items are significant $(p<0.05)$ then the data is not normally distributed then non-parametric tests should be used in further analytical tests (Gaur and Gaur, 2006). 
Table 4. The normality of data distribution- Kolmogorov-Smirnov Test

\begin{tabular}{|c|c|c|c|}
\hline \multirow{2}{*}{ Items } & \multicolumn{3}{|c|}{ Kolmogorov-Smirnov ${ }^{\mathrm{a}}$} \\
\hline & Statistic & df & Sig. \\
\hline \multicolumn{4}{|l|}{ A. Human Resources } \\
\hline Lay off some employees & .434 & 211 & .000 \\
\hline Give employees unpaid leave & .444 & 211 & .000 \\
\hline Reduction of working hours/ days & .434 & 211 & .000 \\
\hline Reducing senior management salaries & .434 & 211 & .000 \\
\hline Reducing all employees' salaries & .442 & 211 & .000 \\
\hline Replacing high wages staff with low salaries new ones & .433 & 211 & .000 \\
\hline Increased reliance on outsourcing & .433 & 211 & .000 \\
\hline \multicolumn{4}{|l|}{ B. Marketing } \\
\hline Intensify marketing efforts on domestic tourism market & .441 & 211 & .000 \\
\hline Advertising campaigns in different media & .435 & 211 & .000 \\
\hline Co-marketing with other tourism services (airlines, hotels) & .439 & 211 & .000 \\
\hline Provide special offers with discounted rates & .449 & 211 & .000 \\
\hline Reduce prices for all services provided by the company & .446 & 211 & .000 \\
\hline $\begin{array}{l}\begin{array}{l}\text { Marketing and promotion of new products/ services } \\
\text { (special events) }\end{array} \\
\end{array}$ & .442 & 211 & .000 \\
\hline Targeting new market segments & .452 & 211 & .000 \\
\hline Participation at international tourism trade/customer fairs & 449 & 211 & .000 \\
\hline \multicolumn{4}{|l|}{ C. Cost reduction } \\
\hline $\begin{array}{l}\text { Cut-off costs by deferring maintenance on company } \\
\text { equipment }\end{array}$ & .433 & 211 & .000 \\
\hline cut-off costs by purchasing cheap office supplies & .473 & 211 & .000 \\
\hline Defer owed operating payment (electricity, other expenses) & .439 & 211 & .000 \\
\hline \multicolumn{4}{|l|}{ D. Government support } \\
\hline $\begin{array}{l}\text { Organize official protests against inadequate government } \\
\text { assistance }\end{array}$ & 444 & 211 & .000 \\
\hline Request long-term government support & .439 & 211 & .000 \\
\hline Request an installment payments agreement (taxes, loans) & .434 & 211 & .000 \\
\hline
\end{tabular}

a. Lilliefors Significance Correction

Then, the Kruskal-Wallis $\chi^{2}$ test was used to identify the differences in the answers of surveyed managers on the basis of the of the travel agency category (A, B, C), company's operating years $(<5$ years, $5-9,10-15,>15$ years), and ownership structure (national, foreign, partnership). The Mann-Whitney U-test was used to identify differences in the managers' opinions on the basis of the company size (SMEs vs. large enterprises). Kruskal-Wallis $\chi^{2}$ test results (table 5) reveled that statistical significant difference occurred at most of crisis management actions across different categories of travel agencies. However, only two actions showed no statistical significant difference, namely "Reduce prices for all services provided by the company" $(\mathrm{H}(2)=1.536, p=0 . .464)$ and "Cut-off costs by deferring maintenance on company equipment" (H (2) 
$=1.342, p=0.511$ ). To investigate which groups significantly differ, a series of Mann-Whitney tests is conducted and showed that this difference was between category A and B as well as between category B and C. This can be ascribed to the fact that travel agents under category B do not offer different products that can reduce its prices or to cut costs during crisis. However, these companies work only on ticketing, with commissions from airlines, which is their main and sole revenue source.

Table 5. Differences in travel agencies 'actions during crisis

\begin{tabular}{|c|c|c|c|c|c|c|}
\hline \multirow{3}{*}{ Item } & \multicolumn{4}{|c|}{ Kruskal-Wallis $\chi^{2}$ test } & \multirow{2}{*}{\multicolumn{2}{|c|}{$\begin{array}{c}\begin{array}{c}\text { Mann-Whitney U- } \\
\text { test }\end{array} \\
\text { Company size }\end{array}$}} \\
\hline & \multicolumn{2}{|c|}{$\begin{array}{l}\text { Travel agency } \\
\text { category }\end{array}$} & \multicolumn{2}{|c|}{$\begin{array}{l}\text { Company } \\
\text { ownership }\end{array}$} & & \\
\hline & $\begin{array}{l}\text { Chi- } \\
\text { Square }\end{array}$ & $\begin{array}{l}\text { Asymp. } \\
\text { Sig. }\end{array}$ & $\begin{array}{l}\text { Chi- } \\
\text { Square }\end{array}$ & $\begin{array}{l}\text { Asym } \\
\text { p. Sig. }\end{array}$ & $\begin{array}{l}\text { Mann- } \\
\text { Whitney } \\
\text { U }\end{array}$ & $\begin{array}{l}\text { Asym } \\
\text { p. Sig. } \\
(2- \\
\text { tailed) }\end{array}$ \\
\hline Lay off some employees & 32.559 & .000 & 17.939 & .000 & 47.500 & .115 \\
\hline Give employees unpaid leave & 30.303 & .000 & 18.540 & .000 & 39.500 & .042 \\
\hline $\begin{array}{l}\text { Reduction of working hours/ } \\
\text { days }\end{array}$ & 12.733 & .002 & 15.040 & .001 & 56.500 & .270 \\
\hline $\begin{array}{l}\text { Reducing senior management } \\
\text { salaries }\end{array}$ & 20.502 & .000 & 16.241 & .000 & 56.000 & .274 \\
\hline $\begin{array}{lll}\text { Reducing all employees' } \\
\text { salaries }\end{array}$ & 29.561 & .000 & 15.406 & .000 & 60.000 & .367 \\
\hline $\begin{array}{l}\text { Replacing high wages staff with } \\
\text { low salaries new ones }\end{array}$ & 20.478 & .000 & 17.746 & .000 & 34.500 & .021 \\
\hline $\begin{array}{lll}\begin{array}{l}\text { Increased } \\
\text { outsourcing }\end{array} & \text { reliance } & \text { on } \\
\end{array}$ & 31.574 & .000 & 17.909 & .000 & 61.000 & .389 \\
\hline $\begin{array}{l}\text { Intensify marketing efforts on } \\
\text { domestic tourism market }\end{array}$ & 10.203 & .006 & 18.926 & .000 & 59.000 & .352 \\
\hline $\begin{array}{l}\text { Advertising campaigns in } \\
\text { different media }\end{array}$ & 9.336 & .009 & 18.962 & .000 & 45.000 & .096 \\
\hline $\begin{array}{l}\text { Co-marketing with other } \\
\text { tourism services (airlines, } \\
\text { hotels) }\end{array}$ & 29.479 & .000 & 29.898 & .000 & 75.500 & .935 \\
\hline $\begin{array}{l}\text { Provide special offers with } \\
\text { discounted rates }\end{array}$ & 20.104 & .000 & 14.741 & .001 & 62.000 & .425 \\
\hline $\begin{array}{l}\text { Reduce prices for all services } \\
\text { provided by the company }\end{array}$ & 1.536 & .464 & 14.240 & .001 & 73.500 & .856 \\
\hline $\begin{array}{l}\text { Marketing and promotion of } \\
\text { new products/ services (special } \\
\text { events) }\end{array}$ & 23.199 & .000 & 15.975 & .000 & 63.000 & .461 \\
\hline Targeting new market segments & 29.465 & .000 & 29.535 & .000 & 69.500 & .689 \\
\hline $\begin{array}{l}\text { Participation at international } \\
\text { tourism trade/customer fairs }\end{array}$ & 13.591 & .001 & 28.120 & .000 & 44.500 & .085 \\
\hline
\end{tabular}




\begin{tabular}{|l|c|c|c|c|c|c|}
\hline \multirow{2}{*}{ Item } & \multicolumn{3}{|c|}{ Kruskal-Wallis $\chi 2$ test } & \multicolumn{2}{c|}{$\begin{array}{c}\text { Mann-Whitney U- } \\
\text { test }\end{array}$} \\
\cline { 2 - 7 } & \multicolumn{2}{|c|}{$\begin{array}{c}\text { Travel agency } \\
\text { category }\end{array}$} & \multicolumn{2}{c|}{$\begin{array}{c}\text { Company } \\
\text { ownership }\end{array}$} & \multicolumn{2}{c|}{ Company size } \\
\cline { 2 - 7 } & $\begin{array}{l}\text { Chi- } \\
\text { Square }\end{array}$ & $\begin{array}{l}\text { Asymp. } \\
\text { Sig. }\end{array}$ & $\begin{array}{l}\text { Chi- } \\
\text { Square }\end{array}$ & $\begin{array}{l}\text { Asym } \\
\text { p. Sig. }\end{array}$ & $\begin{array}{l}\text { Mann- } \\
\text { Whitney } \\
\text { U }\end{array}$ & $\begin{array}{l}\text { Asym } \\
\text { p. Sig. } \\
\text { (2- } \\
\text { tailed) }\end{array}$ \\
\hline $\begin{array}{l}\text { Cut-off costs by deferring } \\
\text { maintenance on company } \\
\text { equipment (e.g buses) }\end{array}$ & 1.342 & .511 & 14.939 & .001 & 76.000 & .959 \\
\hline $\begin{array}{l}\text { cut-off costs by purchasing } \\
\text { cheap office supplies }\end{array}$ & 6.393 & .041 & 43.400 & .000 & 67.000 & .597 \\
\hline $\begin{array}{l}\text { Defer owed operating payment } \\
\text { (electricity, other expenses) }\end{array}$ & 9.677 & .008 & 31.677 & .000 & 62.000 & .436 \\
\hline $\begin{array}{l}\text { Organize official protests } \\
\text { against inadequate government } \\
\text { assistance }\end{array}$ & 21.352 & .000 & 3.058 & .217 & 67.500 & .620 \\
\hline $\begin{array}{l}\text { Request long-term government } \\
\text { support }\end{array}$ & 9.829 & .007 & .022 & .989 & 68.500 & .650 \\
\hline $\begin{array}{l}\text { Request an installment } \\
\text { payments agreement (taxes, } \\
\text { loans) }\end{array}$ & 9.896 & .007 & .010 & .995 & 65.000 & .514 \\
\hline
\end{tabular}

Similarly, the Kruskal-Wallis $\chi^{2}$ test results showed statistical significant difference among most of crisis management actions on the basis of ownership type of travel agencies. But, three actions showed no differences including "Organize official protests inadequate government assistance" $(\mathrm{U}=3.058, p=$ $0.217)$, "Demand long-term government support" $(\mathrm{U}=0.022, p=0.989)$, and "Request an installment payments agreement (taxes, loans)" ( $\mathrm{U}=0.010, p=0$. 995). These three actions related to the requesting support from the government and the difference was between all three types of ownership; national, foreign, and partnership. These results are generally consistent with the findings of (Kukanja, and Planinc 2013) who found that the usage of crisis management practices varies according the ownership structure of companies. Nevertheless, the Kruskal-Wallis $\chi^{2}$ test results did not presented differences between respondents' answers on the basis of the operating years of their company. On the other hand, the Mann-Whitney U-test did not show any statistically significant difference in the crisis management actions between SMEs and large enterprises (Table 5).

These abovementioned results answered the second questions of this current study revealing that actions to be adopted by travel agencies during crises in Egypt are influenced by travel agencies categories and ownership structure. These results were generally different from the results of (Kukanjaand and Planinc, 2013) who indicated that in general there are no statistical significant differences in the usage of different operational crisis management practices according to different food and beverages facilities, forms of business organizations and ownership structure of the food and beverages facilities. 


\section{Conclusion and implications}

In reference to the tourism crisis that Egypt is experiencing since 2011, there is inevitable need to develop crisis management actions plans to be adopted at different levels. Travel agencies business is one of the most affected sectors during crises in any destination and Egypt is no exception. From this sprang, this paper was designed to investigate managers' opinions on their high-level management actions during crises with emphasize on the travel agencies business in Egypt. More specifically, two research questions were formulated to be answered thorough this study: 1) what are the most important actions should be adopted by travel agencies in Egypt during crises? 2) What are the travel agencies' characteristics that influence their actions during crises?. A quantitative questionnaire is designed, based on four dimensions (human resources, marketing, cost reduction, and government support) to collect data from managers in different types of travel agencies in Egypt.

The findings of this current study revealed that travel agnceies have been affacted very badly during the present tourism crisis and the general uncertainty status in Egypt explain the lack of crisis management strategies. Also, the results illustrated that marketing actions should be in the top priorities of management actions during crisis including the following actions: comarketing with other tourism suppliers (e.g. airlines, hotels), provide special offers with discounted rates, targeting new market segments, and marketing and promotion of new products/ services (e.g. special events). Moreover, the actions associated with government support are among the most important crisis management actions including: request long-term government supports, and request an installment payments agreement (e.g. taxes, loans). On contrary, the study found that the actions related to terminating human resources or reducing their salaries were not preferable. Furthermore, it is proved through the study analysis that different categories of travel agencies and the ownership type of companies are influencing the management actions during crises.

As a final point, this study presented important and various actions that are suggested to be adopted by travel agencies in Egypt during crisis, which could help them to relieve the negative effects of crisis and to support developing an efficient crisis management action plan as well. Based on these study findings, managers of travel agencies in Egypt should generally give the following ten actions the top priority when dealing with crises:

- Co-marketing with other tourism suppliers (airlines, hotels)

- Request long-term government supports

- Request an installment payments agreement (taxes, loans)

- Provide special offers with discounted rates

- Targeting new market segments

- Marketing and promotion of new products/ services (special events)

- Reduce prices for all services/products provided by the company

- Participation at international tourism trade/customer fairs

- Advertising campaigns in the internet and social media

- Intensify marketing efforts on domestic tourism market 
Herein, it is worth mentioning that when managers intend to adopt discounting services rates and reducing prices as crises management actions, they should pay attention to keep the high-levels of service quality. Certainly, if they reduced prices by reducing service quality, their crises management efforts would be ultimately unsuccessful. The suggestion for future research is to extend this study method and analysis to other tourism business in Egypt such as hotels and airlines. Also, comparative analysis is required to be explored regarding the different crisis management actions among the different tourism business in Egypt.

\section{References}

Ageron, A. and Courvoisier, D. (2015). Sample size for pre-tests of questionnaires. Quality of Life Research, 24(1), pp.147-151.

Aviad, A., Mohsin, A. and Kumar, B. (2011). Hospitality crisis management practices: The case of Indian luxury hotels. International Journal of Hospitality Management, 30(2), 367-374.

Akova, O., Sarışık, M. and Dönmez, Z. (2011). Strategies for Tourism Industry under the Global Economic Crisis: A SWOT Analysis of Turkish Tourism, International conference on European economics, Session 6A: Tourism \& IT, 382-389.

Avraham, E., (2015). Destination image repair during crisis: Attracting tourism during the Arab Spring uprisings, Tourism Management, 47, 224-232.

Beirman, D. (2003). Restoring Tourism Destinations in Crisis: A Strategic Marketing Approach, CABI Publishing, Wallingford.

Blake, A. and Sinclair, M. (2003). Tourism crisis management: US response to September 11. Annals of Tourism Research, 30(4), pp.813-832.

CAPMAS, Central Agency for Public Mobilization and Statistics (2016). Tourism in Egypt: Annual bulletin. Cairo.

GAFI, General Authority for Investment and Free Zones (2015). Tourism Legislation in Egypt. Retrieved at 20/08/2016 from http://www.gafi.gov.eg/Arabic/StartaBusiness/

Gaur, A. and Gaur, S. (2006). Statistical methods for practice and research: A guide to data analysis using SPSS. Sage.

Henderson, J.C. (2007). Tourism Crises: Causes, Consequences and Management, Oxford: Butterworth-Heinemann.

IDSC, Information and Decision Support Center (2016). Statistical Indicators: Number of travel agencies. Retrieved at 20/08/2016 from http://www.eip.gov.eg/nds/nds_view.aspx?id=4172

Ito, H. and Lee, D. (2005). Assessing the Impact of the September 11 Terrorist Attacks on U.S. Airline Demand, Journal of Economics and Business, 57(1), 75-95.

Kukanja, M. and Planinc, T. (2013). The response of the restaurant industry to the financial crisis. Ekonomska misao i praksa, (1), pp.39-56.

Lahav, T., Mansfeld, Y., and Avraham, E. (2013). Public relations for rural areas, Journal of Tourism and Travel Marketing, 30, 291-307. 
Lovelock, B. (2003). New Zealand travel agent practice in provision of advice for travel risky destinations, Journal of Travel and Tourism Marketing, 15(4), 259-279.

Malhotra, N. (2004). Marketing Research: An Applied Orientation. $4^{\text {th }}$ Edn. Pearson Education, Inc., New Jersey.

McKercher, B. and Chon, K. (2004). The over-reaction to SARS and the collapse of Asian tourism, Annals of Tourism Research, 31(3): 716-719.

Meng, X. (2013). Scalable Simple Random Sampling and Stratified Sampling. In Proceedings of the $30^{\text {th }}$ International Conference on Machine Learning, 16-21 June 2013, USA: Georgia,

Mitroff, I.I. (1988): Crisis Management: Cutting through the Confusion, Sloan Management Review. Winter, 15-20.

Monica, C. and Raluca, D. (2008). Human Resources development- A key element in crisis management, Annals of the University of Oradea, Economic Science Series, 17(4), 275-261.

Paraskevas, A. and Altinay, L. (2013). Signal Detection as the First Line of Defense in Tourism Crisis, Management, Tourism Management, 34(1), 158-171.

Pforr, C. and Hosie, P. (2007). Crisis management in tourism: preparing for recovery, Journal of Travel and Tourism Marketing, 23(2/3/4), pp.249264.

Pine, R. and McKercher, B. (2004). The Impact of SARS on Hong Kong's Tourism Industry, International Journal of Contemporary Hospitality Management, 16(2), 139-143.

Ritchie, B.W., (2004). Chaos, crises and disasters: a strategic approach to crisis management in the tourism industry, Tourism Management, 25, 669-683.

Rittichainuwat, B.N. (2006). Tsunami Recovery: A Case Study of Thailand's Tourism. Cornell Hotel and Restaurant Administration Quarterly, 47(3), 390-404.

Santana, G. (2004). Crisis management and tourism, beyond the rhetoric, In Hall, C.M., Timothy, D.J. and Duval, D.T. (Eds.) Safety and Security in Tourism, Relationships, Management and Marketing (pp.299-322), New York: Haworth Press.

Sausmarez, N. (2003). Malaysia's Response to the Asian Financial Crisis: Implications for Tourism and Sectorial Crisis Management, Journal of Travel and Tourism Marketing, 15(4), pp.217-231.

Sausmarez, N. (2004). Crisis management for the tourism sector: Preliminary considerations in policy development, Tourism and Hospitality Planning and Development, 1(2), 157-172.

Sönmez, S., Backman, K. and Allen, L. (1994). Managing Tourism Crises: A Guidebook. Clemson, SC: Clemson University.

Sonmez, S.F., Apostolopoulos, Y. and Tarlow, P., (1999). Tourism in Crisis: Managing the Effects of Terrorism, Journal of Travel Research, 38 (1), pp.13-18.

Thode, .C. (2002). Testing for normality. (164). CRC press. 
TIA, (2001). The Travel Industry Recovery Coalition Fact Sheet, Travel Industry Association of America. http://tia.org/govaffairs/6pointplan.pdf.

Wang, Y. (2009). The Impact of Crisis Events and Macroeconomic Activity on

Taiwan's International Inbound Tourism Demand, Tourism Management, 30(1), pp.75-82.

Wang, Y. (2010). The Strategies Adopted by Taiwan in Response to the Global Financial Crisis, and Taiwan's Role in Asia-Pacific Economic Integration, Japan and the World Economy, 22, pp.254-263.

Yaron, P. and Aviad A. (2011). Crisis management in the travel agency sector: A case study, Journal of Vacation Marketing, 17(2), 115-125.

\section{إجراعات إدارة الأزمات في شركات السياحة المصرية من وجهة نظر المديرين}

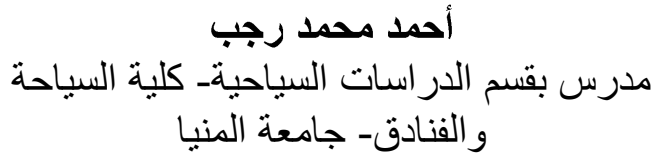

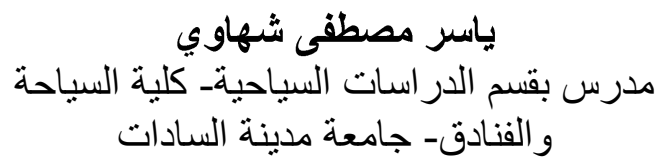

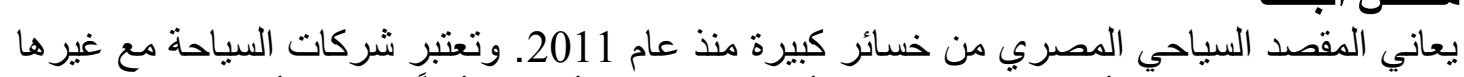

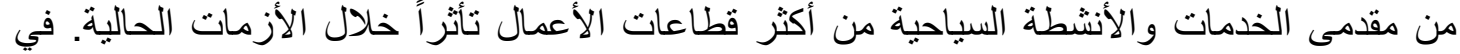

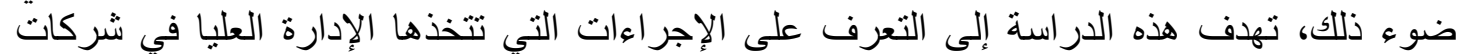

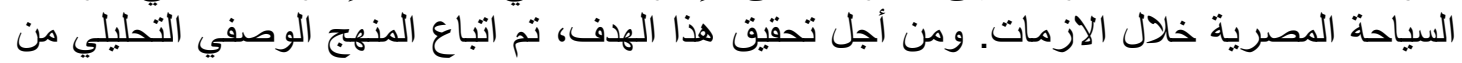

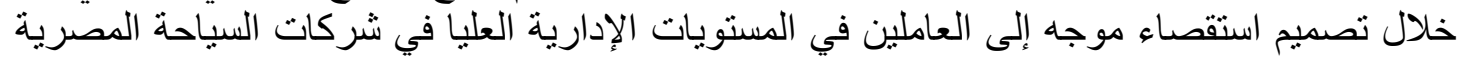

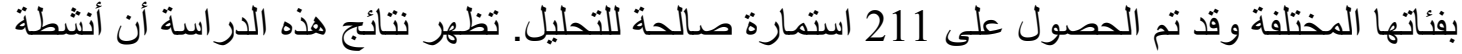

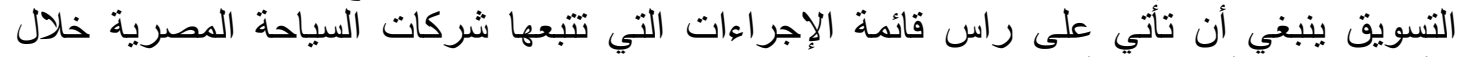

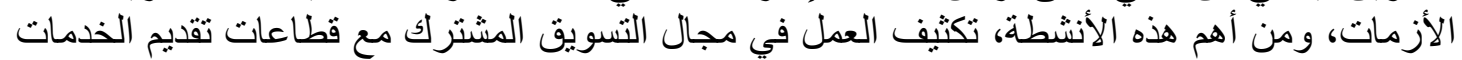

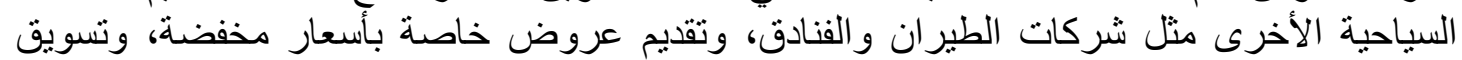

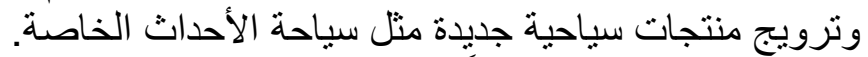

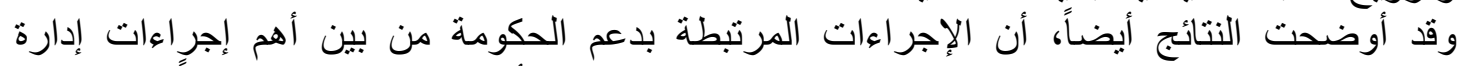

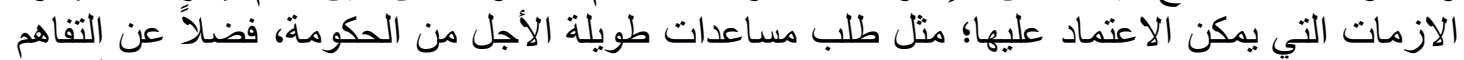

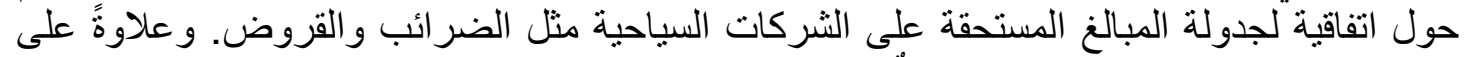

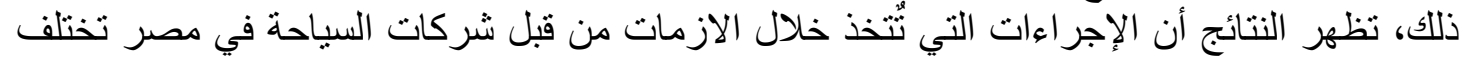

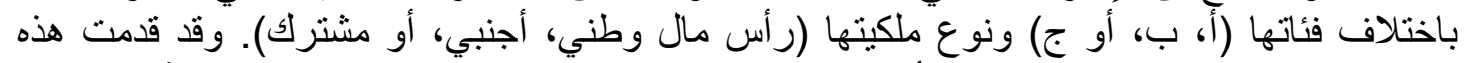

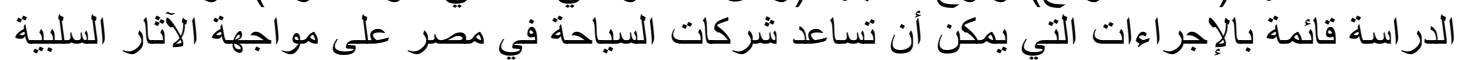

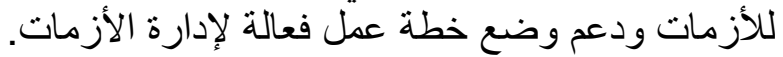
الكلمات الرئيسة: الازمات ودمة السياحية، إدارة الازماتة الإدة شركات السياحة، مصر. 